\title{
Biochemical Characterization of Crude $\alpha$-Amylase of Aspergillus spp. Associated with the Spoilage of Cassava (Manihot esculenta) Tubers and Processed Products in Nigeria
}

\author{
Oghenetega Jonathan Avwioroko", Nyerhovwo John Tonukari, Samuel Ogheneovo Asagba \\ Department of Biochemistry, Faculty of Science, Delta State University, Abraka, Nigeria
}

Email address:

joavwioroko@gmail.com (J. O. Avwioroko), tonukari@gmail.com (N. J. Tonukari), asagbabch@yahoo.com (S.O. Asagba)

To cite this article:

Oghenetega Jonathan Avwioroko, Nyerhovwo John Tonukari, Samuel Ogheneovo Asagba. Biochemical Characterization of Crude $\alpha-$ Amylase of Aspergillus spp. Associated with the Spoilage of Cassava (Manihot esculenta) Tubers and Processed Products in Nigeria. Advances in Biochemistry. Vol. 3, No. 1, 2015, pp. 15-23. doi: 10.11648/j.ab.20150301.14

\begin{abstract}
In this research, crude $\alpha$-amylases associated with the spoilage of cassava (Manihot esculenta) tubers/ product ('eba') were biochemically characterized. They were isolated from five fungi: Aspergillus sp. CSA25, Aspergillus sp. CSA26, Aspergillus sp. CSA27, Aspergillus sp. CSA35 and Aspergillus sp. CSA38. The results of the analyses showed that the activities of $\alpha$-amylase obtained from both sources (cassava tuber/ eba) were optimal at $45^{\circ} \mathrm{C}$ and $\mathrm{pH}$ 5.0. The maximum specific activity $(\mathrm{Vmax})$ of the enzyme was found to be $10 \mathrm{U} / \mathrm{mg}$ protein, while its Michaelis-Menten constant $(\mathrm{Km})$ was between $0.37-1.25 \% \mathrm{w} / \mathrm{v}$. The $\alpha$-amylase is thermally stable for $1-2 \mathrm{~h}$ at optimum temperature and $\mathrm{pH}\left(45^{\circ} \mathrm{C} ; \mathrm{pH} 5.0\right)$. A broad range of substrate specificity was expressed by the enzyme for cassava starch-containing products (tapioca flour, garri flour, cassava flour, 1\%, w/v); however, potato (Ipomoea batatas) starch, yam (Dioscorea rotundata) flour and cocoyam (Colocasia esculenta) flour were relatively minimally hydrolyzed by the crude $\alpha$-amylases obtained from Aspergillus spp. that caused spoilage of cassava. Ethylenediamine tetraacetic acid $\left(1 \mathrm{mM}\right.$ EDTA) and $\mathrm{Mg}^{2+}$ treatment had no significant $(\mathrm{p}>0.05)$ effect on the activities of the amylase, but $\mathrm{Na}^{+}, \mathrm{K}^{+}, \mathrm{Ca}^{2+}, \mathrm{Fe}^{3+}$, thiourea and $5^{\prime}, 5^{\prime}$-dithiobis-2-nitrobenzoate $(1 \mathrm{mM}$ DTNB) enhanced its activities. The fungal $\alpha$-amylases were most activated by $\mathrm{K}^{+}$and had a salt tolerance of $1-2 \mathrm{M} \mathrm{NaCl}$ for $24 \mathrm{~h}$. The fungal $\alpha$-amylases reported in this study would find useful application in industries like food industry, detergent industry, paper industry, textile industry, pharmaceutical industry, etc where microbial $\alpha$-amylases would be required for efficient and cost-effective hydrolysis of cassava starch, cassava flour and or its products.
\end{abstract}

Keywords: Manihot esculenta (Cassava), Aspergillus spp., $\alpha$-Amylase, Biochemical Characterization

\section{Introduction}

Alpha amylase (E.C 3.2.1.1) is an extracellular enzyme that catalyzes the hydrolysis of $\alpha-\mathrm{D}-(1,4)$ glycosidic linkages in starch components and related polysaccharides to release maltose, a disaccharide $[31,29,46]$.

The enzyme is also referred to as 1,4- $\alpha$-D-glucanglucanohydrolase. It is a key enzyme in the production of starch derivatives and has also found reputable application in fabrics designing industries, baking industry, pharmaceuticals and detergents making industries [22, 37]. At present, a renewed interest in the exploration of the enzymatic activity of extracellular enzymes like amylases in several microorganisms has been stimulated in the mind of many research workers that look forward to using such microorganisms as biotechnological sources of industrially relevant enzymes [38, 41, 46, 23, 3]. Most plants, bacteria, fungi and even animals have been severally reported to secrete a number of industrial enzymes like amylases $[43,9$, 22].

Generally, fungi are a group of microorganisms known to grow on substrates to which they can easily secrete digestive enzymes. They have been found growing on foods like rice, bread, cooked garri (a cassava product), cooked yam (Dioscorea rotundata), and even on leather materials (fabrics) undergoing spoilage. Manihot esculenta (cassava), a 

with the Spoilage of Cassava (Manihot esculenta) Tubers and Processed Products in Nigeria

perennial woody shrub, is widely cultivated for its starchy tuberous roots across the tropical and subtropical regions of the world. The tubers and leaves of cassava are highly rich in starch and have also been reported to contain some essential nutrients [20]. When processed or fermented, other cassavabased food products such as dry garri, 'eba', tapioca, 'fufu', 'usi' (cooked starch), 'akpu' (commonly prepared and consumed in the Southern part of Nigeria) are obtained amidst others. Cassava products form a major part of the staple food in the Niger-Delta Region of Nigeria [35; 45].

Due to their rich nutrient contents, cassava tuber and its products tend to support the growth of fungi upon exposure to air for some weeks. According to [43] and [44], most of these microorganisms are able to utilize cassava products as their sole source of carbon because of their ability to secrete starch degrading enzymes, such as amylases, glucoamylase, etc that assist in converting starch to simple digestible sugars.

Normally, the activities of enzymes are known to be affected or regulated by a number of biochemical and physico-chemical factors [24, 16], some of which may interact with the enzyme molecule in a non-covalent manner inducing a temporary, reversible effect (decrease or increase in activity) [25] or in a covalent interaction causing a permanent or irreversible change in the enzyme's conformation (protein denaturature) [18]. Hence, enzymes can be characterized based on their responses to the influence(s) of effector molecules and/ or physico-chemical factors such as change in temperature, $\mathrm{pH}$, presence of a ligand, cofactors (metal ions), affinity for substrate/ substrate specificity, thermal stability, salt tolerance, values of Michaelis-Menten constants (Vmax, Km), etc.

In this study, we biochemically characterized crude $\alpha$ amylases isolated from Aspergillus spp.CSA25-38, previously identified in a preliminary study to be associated with spoilage of cassava ( $M$. esculenta) and its products in Nigeria [6]. This is to provide adequate knowledge of the optimal conditions at which the enzyme can best be applied for potential industrial uses.

\section{Materials and Methods}

\subsection{Harvesting and Processing of Cassava Tubers}

Fresh cassava roots (also called tubers) were harvested from HarmonyPath Farm, Otorho-Agbon, Delta State, using a sharp cutlass. A portion of the tubers was simply peeled (but not processed further) and used as fresh cassava tubers, while the other portion was processed into garri through a series of methods described by [36], that involved peeling the cassava roots, washing, grating, solid state fermentation, pulverizing and roasting or frying to obtain a dry yellow granular cassava product called garri.

\subsection{Preparation of Eba}

This was carried out as described by [5] and [33] with some modifications. Garri, a dry granular processed cassava product, was prepared into a stiff paste or gel called 'eba' by adding the granules into hot water $\left(90-100^{\circ} \mathrm{C}\right)$ in a plastic bowl and stirring to make a paste of desired consistency. The paste (now eba) was later thoroughly mixed with a carved wooden apparatus.

\subsection{Preparation of Cassava Flour}

The method described by [36] was followed with some modifications. Peeled cassava tubers were sliced into chips using a knife and sun-dried to brittle point. The dried cassava chips were grinded into powder form (referred to as cassava flour) using a grinding device (Blender). The cassava flour (powder) was stored at room temperature till later use.

\subsection{Preparation of YPD Agar}

YPD (yeast extract-peptone dextrose) agar was prepared by measuring $2.0 \mathrm{~g}$ of glucose monohydrate, $1.0 \mathrm{~g}$ yeast extract, $2.0 \mathrm{~g}$ peptone and $1.5 \mathrm{~g}$ agar-agar powder into a 250 $\mathrm{ml}$ conical flask. Little volume of distilled water was added to dissolve the flask contents and thereafter, the solution was made up to $100 \mathrm{ml}$ with $\mathrm{dH}_{2} \mathrm{O}$. The solution was sterilized by autoclaving for $15 \mathrm{~min}$ at $121^{\circ} \mathrm{C}$.

\subsection{Growth of Fungal Isolates}

Peeled cassava tubers and $e b a$ were exposed to air for 7 days to allow the cassava-degrading fungi to grow on them. Thereafter, Aspergillus species (Aspergillus sp.CSA25, Aspergillus sp.CSA26, Aspergillus sp.CSA27, Aspergillus sp.CSA35, and Aspergillus sp.CSA38) were collected from the samples [6] with a sterilized spatula and transferred into a sterile YPD agar in a Petri dish and allowed to grow (and sporulate) for one week in the dark. The fungal isolates were then sub-cultured for another 7 days in sterilized Cassava Starch Agar (CSA) containing 2\% cassava flour as the sole source of carbon, $1 \% \mathrm{NaNO}_{2}$ and $1.5 \%$ agar powder to ensure that only cassava starch-degrading fungi grew. $5 \mu 1$ of a $20 \%$ antibiotic (ampicilin) was added to each subculture to prevent growth of bacteria.

\subsection{Fungal Production of Amylase}

This was carried out according to the method described by [26], with little modifications. About 5-10 $\mathrm{ml}$ of sterile normal saline $(0.89 \% \mathrm{NaCl})$ was added to each cassava starch agar (CSA) plate containing grown cassava starchdegrading Aspergillus species (Aspergillus sp.CSA25, Aspergillus sp.CSA26, Aspergillus sp.CSA27, Aspergillus sp.CSA35, and Aspergillus sp.CSA38). A sterile toothpick was used to gently mix the fungi spores with the normal saline and thereafter $2 \mathrm{ml}$ of spore suspension was inoculated into $30 \mathrm{ml}$ of sterilized fungi amylase production medium containing soluble starch $(20 \mathrm{~g} / \mathrm{l}),\left(\mathrm{NH}_{4}\right)_{2} \mathrm{SO}_{4} \mathrm{FeSO}_{4} \cdot 6 \mathrm{H}_{2} \mathrm{O}$ $(0.1 \mathrm{~g} / \mathrm{l}), \mathrm{KH}_{2} \mathrm{PO}_{4}(1.4 \mathrm{~g} / \mathrm{l}), \mathrm{NaNO}_{2}(10 \mathrm{~g} / \mathrm{l}), \mathrm{MgCl}_{2} \cdot 6 \mathrm{H}_{2} \mathrm{O}$ $(0.1 \mathrm{~g} / \mathrm{L}), \mathrm{KCl} 0.5 \mathrm{~g} / \mathrm{l}$, and $\mathrm{H}_{2} \mathrm{O}(1 \mathrm{~L})(\mathrm{pH} 6.5)$. The medium was covered with aluminum foil and incubated at $30^{\circ} \mathrm{C}$ for one week till grown fungal spores, hyphae and colour appearance became visible. The medium was stirred twice daily to ensure even distribution of nutrients, thereby 
facilitating release of more amylase by the fungi to degrade the substrate (soluble starch). $50 \mu \mathrm{l}$ of $20 \%$ antibiotic (ampicilin) was added to each 1 litre of culture medium to prevent growth of bacteria.

\subsection{Isolation of Crude Enzyme Extract}

This was carried out as described by [29] with a slight modification. The fungi hyphae were removed from the growth media using sterile forceps and the growth media containing the extracellular enzyme ( $\alpha$-amylase) were diligently filtered using Whatman No 1 filter paper. The filtrate was kept in a refrigerator $\left(4^{\circ} \mathrm{C}\right)$ and later used for analysis as the crude enzyme.

\subsection{Assay for a-Amylase Activity}

$\alpha$-Amylase activity was determined according to the method described by [31], with some little modifications. The reaction mixture contained $0.5 \mathrm{ml}$ of $1 \%(\mathrm{w} / \mathrm{v})$ soluble starch in $100 \mathrm{mM}$ phosphate buffer $(\mathrm{pH} 6.5)$ and $0.5 \mathrm{ml}$ of enzyme extract. The reaction mixture was incubated for 30 min at $40^{\circ} \mathrm{C}$ and thereafter, $1 \mathrm{ml}$ of 3,5 -dinitrosalicylic acid (DNS) solution was added and heated at $90^{\circ} \mathrm{C}$ for $10 \mathrm{~min}$ to develop red brown colour. Before cooling, $0.3 \mathrm{ml}$ of Rochelle salt (40\% sodium potassium tartrate) was added to stabilize the colour [30]. The colour absorbance was measured at a wavelength of $575 \mathrm{~nm}$ after cooling to room temperature in a cold water bath. The blank was prepared using $0.5 \mathrm{ml}$ of enzyme extract that has already been boiled for $15 \mathrm{~min}$ (to inactivate the enzyme) and all other assay conditions followed. Maltose was used to construct a standard curve. One unit (U) of amylase activity was defined as the amount of enzyme that released $1 \mu \mathrm{g}$ of maltose (as reducing sugar equivalent) per $\mathrm{ml}$ per min under the assay conditions. Specific activity is expressed as amylase activity (U) per mg of protein.

\subsection{Biochemical Characteristics of the Enzyme}

\subsubsection{Effect of Temperature on Amylase Activity}

To determine the optimum temperature as well as effect of temperature on the fungi amylase activity, the activity of amylase isolated from the fungi isolates was measured at different temperatures $\left(25-60^{\circ} \mathrm{C}\right)$ following the assay conditions [29].

\subsubsection{Effect of pH on Amylase Activity}

Measurement of optimum $\mathrm{pH}$ for amylase activity was carried out under the assay conditions for $\mathrm{pH}$ range of 3.010.0 , using $50 \mathrm{mM}$ of three buffer solutions: Glycine- $\mathrm{HCl}(\mathrm{pH}$ 2.2-3.6), sodium acetate ( $\mathrm{pH} 3.6-5.6)$, potassium phosphate (pH 5.8- 8.0) and glycine-NaOH (pH 8.6-10.6). The method described by [44] was followed with some little modifications.

\subsubsection{Effect of Metal Ions on Amylase Activity}

To ascertain the effect of metal ions $\left(\mathrm{NaCl}, \mathrm{KCl}, \mathrm{MgCl}_{2}\right.$, $\mathrm{CaCl}_{2}$, and $\mathrm{FeCl}_{3}$ ) on amylase activity, the enzyme assay was performed after pre-incubation of enzyme extract with the metal ion at a final concentration of $1 \mathrm{mM}$ in $100 \mathrm{mM}$ phosphate buffer ( $\mathrm{pH} 6.5$ ) for $30 \mathrm{~min}$ at $40^{\circ} \mathrm{C}$ according to [44], with some little modifications.

\subsubsection{Effect of Chelating Agent (EDTA), Thiourea and DTNB on Amylase Activity}

The effects of thiourea, DTNB and chelating agent on amylase activity were also evaluated by pre-incubating the enzyme in the presence of the effectors $(1 \mathrm{mM})$ for $30 \mathrm{~min}$ at $40^{\circ} \mathrm{C}[44]$.

\subsubsection{Enzyme Substrate Specificity}

The substrate specificity of the Aspergillus spp. $\alpha$ amylases was determined using cassava flour, yam flour, cocoyam flour, potato flour, garri flour, tapioca flour and soluble starch (as control). Substrate solutions were prepared in $100 \mathrm{mM}$ phosphate buffer $(\mathrm{pH}$ 6.5) at a concentration of $1 \% \mathrm{w} / \mathrm{v}$ and the hydrolytic activity was measured following the standard assay procedures [29].

\subsubsection{Determination of Kinetic Constants (Km and Vmax)}

The effect of different concentrations $(0.2-1.0 \% \mathrm{w} / \mathrm{v})$ of soluble starch on amylase activity was determined under standard assay conditions. The kinetic rate constants, $\mathrm{Km}$ and Vmax values, were calculated after extrapolations from the Lineweaver-Burk plot.

\subsubsection{Salt Tolerance}

In order to determine salt tolerance capacity of the amylase, the enzyme extracts were incubated at final concentrations of $1-3 \mathrm{M} \mathrm{NaCl}$ at $4{ }^{\circ} \mathrm{C}$ for 2 and $24 \mathrm{~h}$, respectively. After incubation, the enzyme activities were measured under standard assay conditions (29].

\subsubsection{Enzyme Stability}

The stability of the amylases at temperature $45^{\circ} \mathrm{C}$ and $\mathrm{pH}$ 5.0 was ascertained by subjecting the enzyme extracts to $\mathrm{pH}$ 5.0 and incubating at $45^{\circ} \mathrm{C}$ for different periods, ranging from $1-4 \mathrm{~h}$, respectively. After the incubation, the enzyme activities were measured under standard assay conditions [29].

\subsubsection{Total Protein Measurement}

Protein was measured by the method of [47] with bovine serum albumin (BSA) as standard. The concentration of protein in each fungi amylase extract was calculated from a standard curve.

\section{Results}

\subsection{Effect of Temperature on the Activity of the Amylase}

$45^{\circ} \mathrm{C}$ was determined to be the optimum temperature for the Aspergillus spp. $\alpha$-amylases investigated (Figure 1). The activities of the $\alpha$-amylases were quite very low at room temperature $\left(25^{\circ} \mathrm{C}\right)$, steadily increased between temperatures $30-40^{\circ} \mathrm{C}$, and eventually peaked at $45^{\circ} \mathrm{C}$. At temperatures above $45^{\circ} \mathrm{C}$ the amylase activities of the fungi grown on cassava tubers (Aspergillus sp. CSA25, Aspergillus sp. 

with the Spoilage of Cassava (Manihot esculenta) Tubers and Processed Products in Nigeria

CSA26, and Aspergillus sp. CSA28) and eba (Aspergillus sp. CSA27 and Aspergillus sp. CSA35) tend to decrease, respectively (Figure 1).

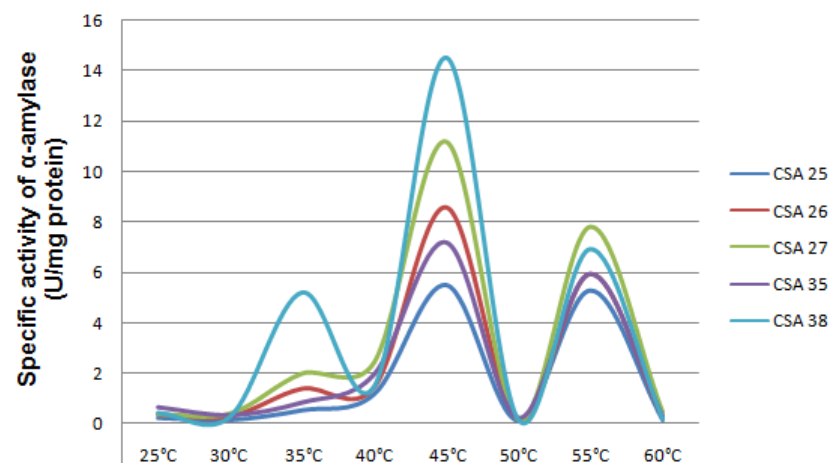

Figure 1. Effect of temperature change on activities of $\alpha$-amylases of Aspergillus spp. associated with cassava spoilage. CSA25, CSA26, and CSA38 are Aspergillus spp. associated with spoilage of cassava; CSA27 and CSA35, are Aspergillus spp. associated with spoilage of eba.

\subsection{Effect of pH on Fungi Amylase Activities}

The specific activity of $\alpha$-amylases isolated from Aspergillus spp. associated with spoilage of cassava was optimum within the $\mathrm{pH}$ range of 4.0-5.0 (Figure 2). While amylases from Aspergillus spp. in cassava tuber (CSA 25, 26, and CSA 38) peaked at $\mathrm{pH} 4.0,5.0$, and 5.0 respectively, those from eba (CSA 27 and 35) peaked at pH 8.0 and 5.0. The optimum $\alpha$-amylase activities of Aspergillus spp. CSA25 (pH 4.0), CSA26 (pH 5.0), CSA35 (pH 5) and CSA38 (pH 5) were about 53, 70, 92 and $86 \%$, respectively, higher than that measured at the normal assay condition ( $\mathrm{pH}$ 6.5). Correspondingly, the optimum amylase activity of Aspergillus sp. CSA27 (obtained at pH 8.0) was only about $50 \%$ higher than that measured at the normal assay condition. These data indicate that the $\alpha$-amylase activities of the cassava-degrading Aspergillus spp. are higher at relatively acidic $\mathrm{pH}$ values ( $\mathrm{pH}$ ).

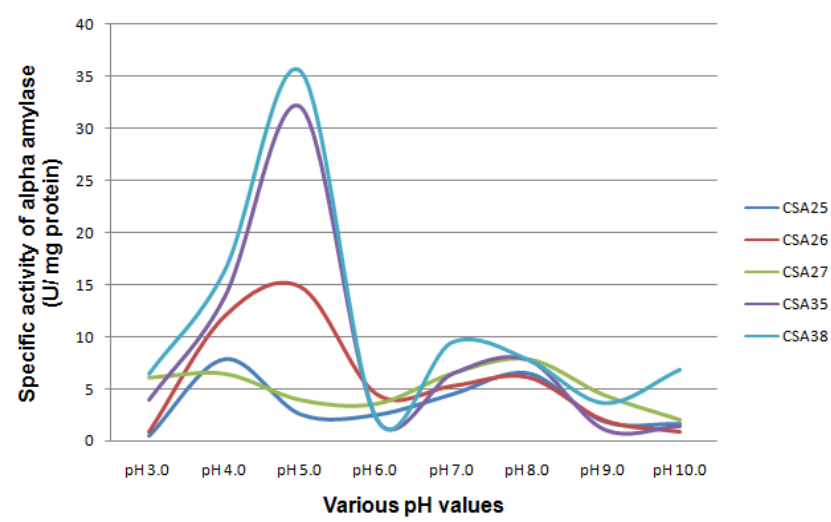

Figure 2. Effect of pH change on activities of $\alpha$-amylases of Aspergillus spp. associated with cassava spoilage. CSA25, CSA26, and CSA38 are Aspergillus spp. associated with spoilage of cassava; CSA27 and CSA35, are Aspergillus spp. associated with spoilage of eba.

\subsection{Effect of Metal Ions on $\alpha$-Amylase Activity}

As indicated in Figure 3, the enzyme activities of $\alpha$ - amylases from the cassava-degrading Aspergillus spp. were strongly activated by potassium ion $\left(\mathrm{K}^{+}\right)$and moderately activated by $\mathrm{Ca}^{2+}$ and $\mathrm{Fe}^{3+}$. The enzyme was, however, slightly stimulated by $\mathrm{Na}^{+}$and $\mathrm{Mg}^{2+}$. In some of the cassava fungi amylases investigated (Aspergillus spp. CSA25 and CSA35), the amylase was partially inhibited by $\mathrm{Mg}^{2+}$.

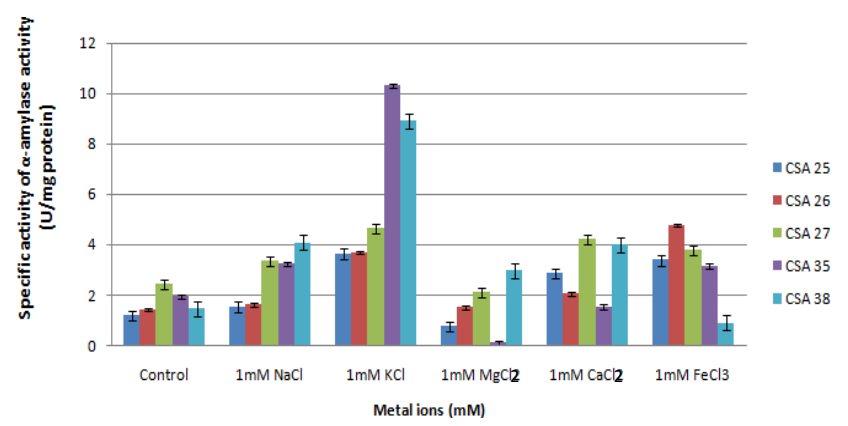

Figure 3. Effect of metal ions (mM) on activities of $\alpha$-amylases of Aspergillus spp. associated with cassava spoilage. CSA25, CSA26, and CSA38 are Aspergillus spp. associated with spoilage of cassava; CSA27 and CSA35, are Aspergillus spp. associated with spoilage of eba.

\subsection{Effect of Thiourea, DTNB and Chelating Agent (EDTA) on a-Amylase Activity}

From the results in Figure 4, it was observed that the activities of $\alpha$-amylases of all the Aspergillus spp. (CSA 2538 ) associated with cassava spoilage were slightly stimulated in the presence of $1 \mathrm{mM}$ thiourea and $1 \mathrm{mM} 5,5^{\prime}$-dithiobis-(2nitrobenzoic acid) (DTNB or Ellman's reagent). However, the presence of the chelating agent, ethylenediamine tetraacetic acid (EDTA, 1mM) weakly inhibited the enzyme activity (Figure 4) in Aspergillus spp.CSA27 and CSA35 (unlike in Aspergillus spp.CSA25, CSA26, and CSA38).

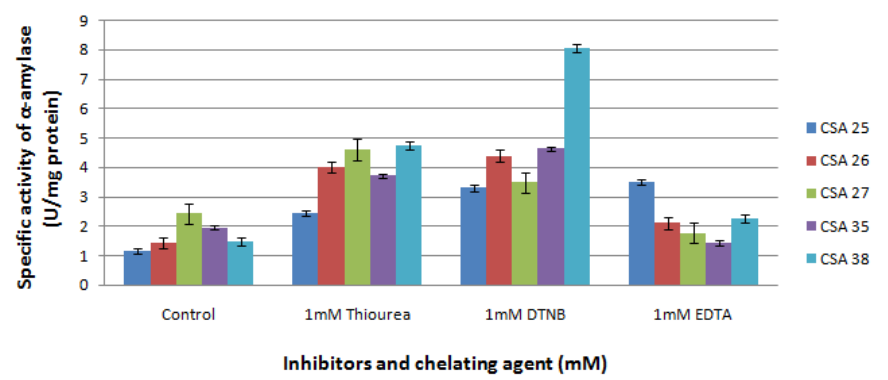

Figure 4. Effect of thiourea, DTNB and EDTA on activities of $\alpha$-amylases of Aspergillus spp. associated with cassava spoilage. CSA25, CSA26, and CSA38 are Aspergillus spp. associated with spoilage of cassava; CSA27 and CSA35, are Aspergillus spp. associated with spoilage of eba.

\subsection{Substrate Specificity}

The $\alpha$-amylases of Aspergillus spp.CSA25-38 expressed higher activities for hydrolysis of cassava starch containing products (cassava flour, garri flour and tapioca flour) than for the non cassava starch products such as yam (Diascorea rotundata) flour, cocoyam (Colocasia esculenta) flour and potato (Ipomea batatas) flour (Figure 5). This observation or pattern of hydrolysis reveals that the cassava-degrading Aspergillus spp. $\alpha$-amylases have a unique broad range of 
substrate specificity for cassava starch products and an extremely low affinity for non cassava starch products.

\subsection{Kinetic Constants (Km and Vmax)}

Michaelis-Menten type kinetics was shown by the $\alpha$ amylases isolated from Aspergillus spp associated with cassava spoilage using soluble starch as substrate. As calculated from the Lineweaver-Burk plots (Table 1), the Vmax of the $\alpha$-amylases of Aspergillus spp. associated with cassava spoilage ranges from $5.56-10.00 \mathrm{U} / \mathrm{mg}$ protein, while the $\mathrm{Km}$ values are within the range of $0.37-1.25 \% \mathrm{w} / \mathrm{v}$. The highest rate of catalysis was found in $\alpha$-amylase from the Aspergillus sp.CSA27 (Vmax $=10 \mathrm{U} / \mathrm{mg}$ protein), while the highest affinity for substrate was shown by $\alpha$-amylase from
Aspergillus sp. CSA38 $(\mathrm{Km}=0.37 \% \mathrm{w} / \mathrm{v})($ Table 1$)$.

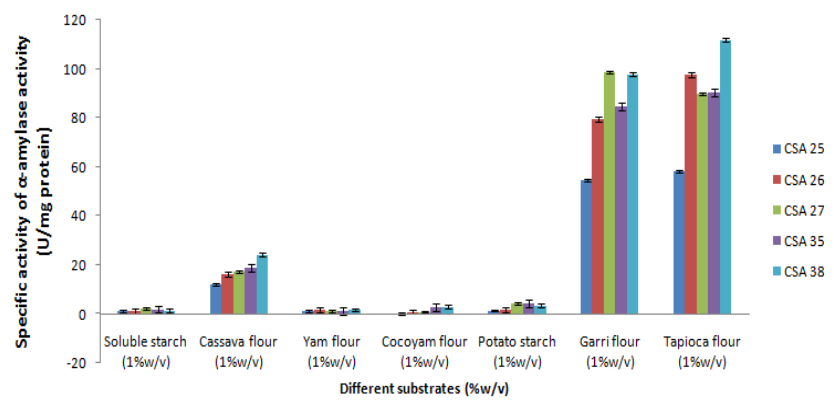

Figure 5. Substrate specificity of $\alpha$-amylases of Aspergillus spp. associated with cassava spoilage. CSA25, CSA26, and CSA38 are Aspergillus spp. associated with spoilage of cassava; CSA27 and CSA35, are Aspergillus spp. associated with spoilage of eba.

Table 1. Km and Vmax values of amylase of cassava-degrading fungi extrapolated from Lineweaver-Burk plots.

\begin{tabular}{|c|c|c|c|c|c|}
\hline \multirow{2}{*}{$\begin{array}{l}\text { Kinetic } \\
\text { isolated }\end{array}$} & \multicolumn{5}{|c|}{ Cassava-degrading fungi } \\
\hline & $\begin{array}{l}\text { Aspergillus } \\
\text { sp.CSA25 }\end{array}$ & $\begin{array}{l}\text { Aspergillus } \\
\text { sp.CSA26 } \\
\end{array}$ & $\begin{array}{l}\text { Aspergillus } \\
\text { sp.CSA27 }\end{array}$ & $\begin{array}{l}\text { Aspergillus } \\
\text { sp.CSA35 }\end{array}$ & $\begin{array}{l}\text { Aspergillus } \\
\text { sp.CSA38 } \\
\end{array}$ \\
\hline $\mathrm{Km}(\% \mathrm{w} / \mathrm{v})$ & 0.57 & 1.25 & 0.91 & 0.67 & 0.37 \\
\hline Vmax (U/mg protein) & 5.56 & 6.67 & 10.0 & 6.90 & 9.01 \\
\hline
\end{tabular}

Km, Michaelis-Menten constant; Vmax, specific maximum enzyme activity; Aspergillus sp.CSA25, Aspergillus sp.CSA26, and Aspergillus sp.CSA38 are Aspergillus species associated with spoilage of cassava; Aspergillus sp.CSA27 and Aspergillus sp.CSA35, are Aspergillus species associated with spoilage of eba.

\subsection{Salt Tolerance}

The ability of the $\alpha$-amylases of Aspergillus spp.CSA 2538 , associated with cassava spoilage, to tolerate or withstand various concentrations of sodium chloride $(1,2$ and $3 \mathrm{M})$ for $24 \mathrm{~h}$ was tested. The result (Figures 6) showed that the activities of the $\alpha$-amylases increased with increasing salt concentration (1 $-2 \mathrm{M} \mathrm{NaCl})$ for $24 \mathrm{~h}$. However, the $\alpha$ amylase activities were observed to decline when the salt concentration was increased beyond 2 to $3 \mathrm{M}$.

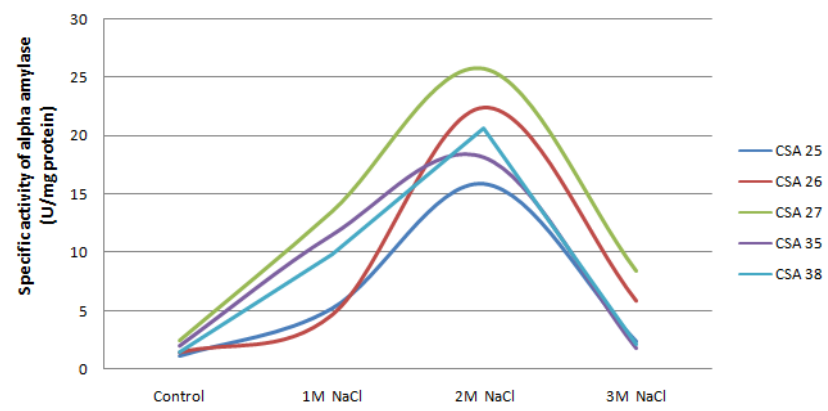

Figure 6. Aspergillus species amylase salt tolerance for 24 h. CSA25, CSA26, and CSA38 are Aspergillus spp. associated with spoilage of cassava; CSA27 and CSA35, are Aspergillus spp. associated with spoilage of eba.

\subsection{Enzyme Stability at Optimum Temperature $\left(45^{\circ} \mathrm{C}\right)$ and pH (5.0)}

From the results shown in Figure 7, the activity of the $\alpha$ amylase after being incubated at the optimum temperature and $\mathrm{pH}\left(45^{\circ} \mathrm{C}, \mathrm{pH} 5.0\right)$ steadily increased for the first $1-2 \mathrm{~h}$, but subsequently declined upon further incubations for 2.5 , 3.0, 3.5 and $4.0 \mathrm{~h}$ at the same temperature and $\mathrm{pH}$ conditions.
The results show that the Aspergillus spp. $\alpha$-amylases are thermally stable for $1-2 \mathrm{~h}$ at $45^{\circ} \mathrm{C}$ and $\mathrm{pH}$ 5.0.

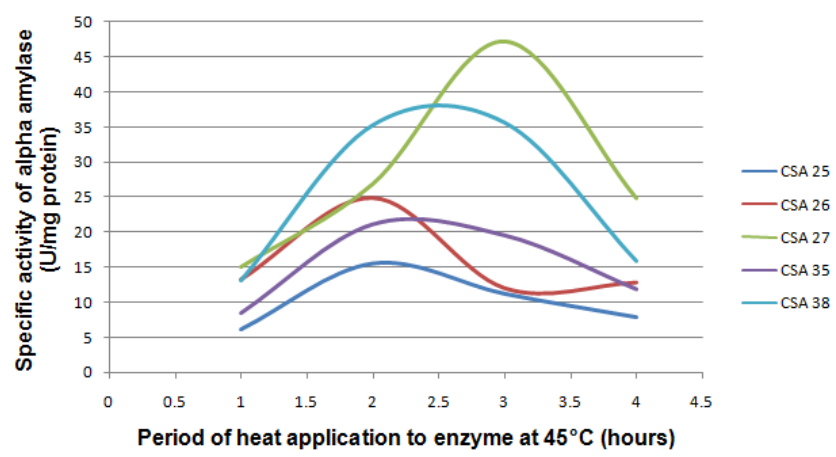

Figure 7. Enzyme stability at optimum temperature $\left(45^{\circ} \mathrm{C}\right)$ and $\mathrm{pH}(5.0)$ of amylase isolated from Aspergillus species. CSA25, CSA26, and CSA38 are Aspergillus spp. associated with spoilage of cassava; CSA27 and CSA35, are Aspergillus spp. associated with spoilage of eba.

\section{Discussion}

In this investigation, $\alpha$-amylases of Aspergillus species associated with spoilage of cassava (Manihot esculenta) were biochemically characterized. The Aspergillus spp. had previously been identified using traditional microbiology approach and 18S rRNA gene sequences as Aspergillus sp.CSA25, Aspergillus sp.CSA26, Aspergillus sp.CSA27, Aspergillus sp.CSA35 and Aspergillus sp.CSA38, as reported by [6].

The activities of enzymes are generally affected or regulated by a number of biochemical and physico-chemical factors $[24,16]$, some of which may interact with the enzyme molecule in a non-covalent manner inducing a temporary 
effect (decrease or increase in activity) [25] or in a covalent interaction causing a permanent or irreversible change in the enzyme's conformation (protein denaturature) [18]. Hence, enzymes can be characterized based on their responses to the influence(s) of effector molecules and or physico-chemical factors such as change in temperature, $\mathrm{pH}$, presence of a ligand, cofactors (metal ions), affinity for substrate/ substrate specificity, thermal stability, salt tolerance, values of Michaelis-Menten constants (Vmax, Km), etc.

As reported by [23] and [42], the optimum temperature for $\alpha$-amylases from fungal and yeast sources has generally been found to be between 30 and $70^{\circ} \mathrm{C}$. Studies on Penicillium species (a fungus) reported its $\alpha$-amylase optimum temperatures to be between 30 and $60^{\circ} \mathrm{C}[14,15,7,40,17]$. Similarly, [31] and [32] had also reported an optimum temperature of 30 and $60^{\circ} \mathrm{C}$ for Penicillium camemberti PL21 and Saccharomyces cerevisae, respectively. These reports are consistent with our findings in which the optimum temperature for the Aspergillus species $\alpha$-amylases is $45^{\circ} \mathrm{C}$ (Figure 1).

The results of the effect of $\mathrm{pH}$ on the $\alpha$-amylase activity of Aspergillus species (Figure 2) show that majority of $\alpha$ amylases are optimally active at $\mathrm{pH}$ 5.0, a relatively acidic $\mathrm{pH}$. The optimum $\alpha$-amylase activities of Aspergillus sp.CSA25 (pH 4.0), Aspergillus sp. CSA26 (pH 5.0), Aspergillus sp.CSA35 (pH 5) and Aspergillus sp.CSA 38 (pH 5) were about 53,70, 92 and $86 \%$, respectively, higher than the ones measured at the normal assay condition $(\mathrm{pH} 6.5)$. Correspondingly, the optimum amylase activity of Aspergillus sp.CSA27 (obtained at pH 8.0) was only about $50 \%$ higher than that measured at the normal assay condition. The results indicate that significantly higher enzyme activities were obtained at the acidic $\mathrm{pH}, 5.0$. Cassava $(M$. esculenta) is naturally acidic due to its rich content of thiocyanic acid [45, 8]. This acidity is, however, reduced when cassava is processed under intense heat and by the addition of palm oil. According to [45], who reported the effect of different processing methods on cyanide content of garri from cultivars of cassava, the volatile thiocyanic acid dissociates under heat, leaving cassava products (such as garri, eba fufu, akpu, tapioca) less acidic for human consumption. It could, therefore, be expected of fungi growing on and degrading cassava tubers/products to be able to secrete amylases with optimum activities predominantly within acidic $\mathrm{pH}$ ranges. This finding is in agreement with those of [23] who reported that the optimum $\mathrm{pH}$ values for $\alpha$ amylases from most bacteria and fungi are within acidic to neutral range. The finding of the present study is also in line with that of [1] who reported an optimum $\mathrm{pH}$ of 5.0 in their work on the $\alpha$-amylase activity of a mutant strain of Aspergillus oryzae EMS-18 in Pakistan.

Metal ions have been widely shown to participate in regulation of enzyme activities. According to [41], metal ions could play key roles in enzyme stability and activity. The effects of metal ions on several $\alpha$-amylases from fungi and yeast have also been reported [29]. $\alpha$-Amylase is a metalloenzyme which contains at least one activating $\mathrm{Ca}^{2+}$ ion [23] and enhancement of amylase activity by metal ions such as $\mathrm{K}^{+}, \mathrm{Ca}^{2+}, \mathrm{Na}^{+}$and $\mathrm{Fe}^{3+}$ could be based on its ability to interact with negatively charged amino acid residues such as aspartic and glutamic acid (Linden et al., 2003). This, in turn, could result in stabilization as well as maintenance of enzyme's conformation [29]. In this study, the enzyme activities of $\alpha$-amylases from the cassava-degrading Aspergillus spp. were strongly activated by potassium ion $\left(\mathrm{K}^{+}\right)$and moderately activated by $\mathrm{Ca}^{2+}$ and $\mathrm{Fe}^{3+}$ (Figure 3 ). The enzyme was, however, slightly stimulated by $\mathrm{Na}^{+}$and $\mathrm{Mg}^{2+}$. In some of the cassava fungi amylases investigated (Aspergillus spp.CSA25 and CSA35), the amylase was partially inhibited by $\mathrm{Mg}^{2+}$. These findings are partly in agreement with the report of Linden et al. (2003) who observed that the activity of $\alpha$-amylases could be slightly enhanced by metal ions such as $\mathrm{K}^{+}, \mathrm{Ca}^{2+}, \mathrm{Na}^{+}$and $\mathrm{Fe}^{3+}$.

Figure 4 shows the effect of thiourea, 5,5'-dithiobis-(2nitrobenzoic acid) [DTNB], and ethylenediamine tetraacetic acid (EDTA) on the activity of $\alpha$-amylases of Aspergillus spp associated with spoilage of cassava. It was observed that the enzyme activity was slightly stimulated in the presence of thiourea and 5,5'-dithiobis-(2-nitrobenzoic acid) [DTNB]. This indicates that cysteine residue(s) do not take part in catalysis [27]. Also, the enzyme activation by DTNB could be attributed to the reduction in aggregate size by destroying the intermolecular disulfide linkages and/or by the protection of thiol groups that stabilize the three dimensional structure of enzyme [27]. Thiourea also appeared to have slightly stimulated the amylase activity, though non-significantly lower than DTNB. Similar result has also been reported for $\alpha$-amylase from Thermococcus profundus DT5432 [10]. The presence of EDTA, a chelating agent, weakly inhibited the amylase activity of Aspergillus sp. CSA27 and Aspergillus sp.CSA35 (unlike in Aspergillus sp. CSA25, Aspergillus sp. CSA26, and Aspergillus sp. CSA38), indicating that the amylases from Aspergillus sp. CSA27 and Aspergillus sp.CSA35 are likely metalloenzymes. Similar results were reported by [40, 42, 37, 23].

The substrate specificity of the $\alpha$-amylase of Aspergillus species associated with spoilage of cassava (M. esculenta) is shown in Figure 5. The fungal $\alpha$-amylases exhibited broad substrate specificity, showing intensive capacity for hydrolysis of $\alpha-1,4$ glycosidic bonds. The hydrolysis of $\alpha$ glucans such as cassava starch-containing products (cassava flour, garri flour and tapioca flour) was more efficient than those of yam (Diascorea rotundata) flour, cocoyam (Colocasia esculenta) flour and potato (Ipomea batatas) flour (Figure 5). According to [29], the substrate specificity of $\alpha$ amylase varies from microorganism to microorganism and the hydrolytic rate of the substrates is affected not only by its molecular size and structure but also by the types of bonds in its chain $[19,29]$. Additionally, variations in starch granule surface area and the presence of amorphous regions in the vicinity of the granule surface of the various substrates tested may have contributed considerably to the differences in susceptibility of the test starches to enzyme attack [29, 34]. A cursory observation of the pattern of hydrolysis reveals that 
the $\alpha$-amylases of the Aspergillus species associated with cassava spoilage have a unique broad range of substrate specificity for cassava starch products and an extremely low affinity for non cassava starch products. The enzyme was able to hydrolyze the starch molecules in the two processed cassava products (garri and tapioca) more than the unprocessed cassava flour possibly because of the effect of the processing (Figure 5). However, very little or no affinity was shown to the non-cassava based products (yam flour, cocoyam flour, potato starch); hence they were minimally hydrolyzed by $\alpha$-amylase of the Aspergillus species associated with cassava spoilage (Figure 5). This appears to be in agreement with the report of [29], who asserted that the substrate specificity of $\alpha$-amylase as well as the hydrolytic rate of the substrates is affected not only by their molecular sizes and structures but also by the types of bonds in their chains.

The relatively low $\mathrm{Km}$ value $(0.37-1.25 \% \mathrm{w} / \mathrm{v}$ of soluble starch) obtained (Table 1) indicates that $\alpha$-amylase has a relatively high affinity for its substrate, starch (Roy et. al., 2014). This may be due to an increased number of interactions between the active site of the enzyme and the substrate molecule, resulting in an increased affinity of the enzyme [39]. The relatively high affinity of the infesting Aspergillus spp $\alpha$-amylases could be the biochemical rationale why cassava tubers or wet cassava products take just a few days to be invaded by these saprophytes [21]. Upon invasion, the saprophytic fungi (Aspergillus spp) gradually degrade or metabolize cassava starch in the long run to support their growth [21]. In a bigger view, the industrial strength/applicability of the $\alpha$-amylases from Aspergillus species associated with cassava spoilage lies greatly on their high substrate specificity (Figure 5) as well as their high affinity for cassava starch (Table 1). These findings are in agreement with the report of [28] who reported a $\mathrm{Km}$ value of $3.7 \mathrm{mg} / \mathrm{ml}$ (i.e $0.37 \% \mathrm{w} / \mathrm{v}$ ) for $\alpha$ amylase produced by Fusarium solani using submerged fermentation.

As reported by [29], enzyme's salt tolerance test is important in saccharification of starch and in treatment of effluent with high salinity containing starch or cellulose residues in pollution control mechanism. In this present study, the ability of the $\alpha$-amylases of the Aspergillus spp.CSA2538 associated with cassava spoilage to tolerate or withstand various concentrations of sodium chloride (1, 2 and $3 \mathrm{M})$ for $24 \mathrm{~h}$ was tested. The result (Figures 6) showed that the activities of the $\alpha$-amylases increased with increasing salt concentration ( $1-2 \mathrm{M} \mathrm{NaCl}$ ) for $24 \mathrm{~h}$. However, $\alpha$-amylase activities were observed to decline when the salt concentration was increased beyond 2 to $3 \mathrm{M}$. These findings are, however, not in full agreement with reports of some researchers in previous studies done on some microbial $\alpha$ amylases in which about $60 \%$ loss of enzyme activity was observed at different salt concentrations $[11,4]$. In the present study, the activity of $\alpha$-amylase first increased with increase in salt concentration from 1 to $2 \mathrm{M}$, and later decreased upon further increase in salt concentration to $3 \mathrm{M}$, indicating that the amylases were only tolerant to 1-2 M $\mathrm{NaCl}$ concentration over a period of $24 \mathrm{~h}$. From this result, it could be inferred that $\alpha$-amylases of the Aspergillus species associated with cassava spoilage would be very useful in industrial processes involving high salt treatment as these enzymes can tolerate or even take advantage of high salt treatment of about 1-2 $\mathrm{M} \mathrm{NaCl}$ up till $24 \mathrm{~h}$.

As shown in Figure 7 , the activity of the $\alpha$-amylase after being incubated at the optimum temperature and $\mathrm{pH}\left(45^{\circ} \mathrm{C}\right.$, $\mathrm{pH}$ 5.0) steadily increased for the first $1-2 \mathrm{~h}$, but subsequently declined upon further incubations for 2.5, 3.0, 3.5 and $4.0 \mathrm{~h}$ at the same temperature and $\mathrm{pH}$ conditions. The enzyme showed good stability at the optimal condition of $45^{\circ} \mathrm{C}$ and $\mathrm{pH} 5.0$ for $1-2 \mathrm{~h}$. This property of the $\alpha$-amylases of Aspergillus species associated with cassava spoilage could be used in biotechnological applications. The enzyme is moderately thermostable when compared with $\alpha$-amylases isolated from Aspergillus niger and Bacillus licheniformis reported to be thermally stable at $20-60^{\circ} \mathrm{C}$ for $2 \mathrm{~h}$ [2].

\section{Conclusion}

From the findings of the present study, it could be concluded that $\alpha$-amylases from Aspergillus species associated with spoilage of cassava ( $M$. esculenta) are optimally active at $45^{\circ} \mathrm{C}$ and $\mathrm{pH} 5.0$; salt tolerant at $1-2 \mathrm{M}$ $\mathrm{NaCl}$ for 24 hours; have a broad range of substrate specificity for cassava starch products and an extremely low affinity for non cassava starch products. These $\alpha$-amylases can easily be activated with potassium ion $\left(\mathrm{K}^{+}\right)$amidst other metal ions. The fungal $\alpha$-amylases reported in this study would find useful application in industries like food industry, detergent industry, paper industry, textile industry, pharmaceutical industry, etc $[12,13]$ where microbial $\alpha$-amylases would be required for efficient and cost-effective hydrolysis of cassava starch, cassava flour and or its products.

\section{References}

[1] Abdullah, R., and Ikram-ul-Haq. Purification and characterisation of $\alpha$-amylase produced by mutant strain of Aspergillus oryzae EMS-18. Natural product research (aheadof-print), 2014; 1-7.

[2] Adeniran, H. A., and Abiose, S. H. Partial purification, characterization and hydrolytic activities of amylases from Bacillus licheniformis and Aspergillus niger cultured on agricultural residues. Afri. J. Biotechnol., 2014; 11(6): 14651477.

[3] Akpan I., MO Bankole and AM Adesemowo. Production of alpha amylase by Aspergillus niger in a cheap solid medium using rice bran and agricultural material. Trop. Sci., 1999; 39: 77-79.

[4] Al-Qodah Z, Daghstani H, Geopel Ph, Lafi W. Determination of kinetic parameters of $\alpha$-amylase producing thermophile Bacillus sphaericus. Afr. J. Biotechnol., 2007; 6: 699-706.

[5] Asegbeloyin J.N., and Onyimonyi A.E. The effect of different processing methods on the residual cyanide of 'Gari'. Pak. J. Nutr., 2007; 6(2): 163-166. 

with the Spoilage of Cassava (Manihot esculenta) Tubers and Processed Products in Nigeria

[6] Avwioroko, J.O. and Tonukari, N.J. Isolation and molecular identification of Aspergillus species associated with the spoilage of cassava in Nigeria. Nig. J. Sci. Environ., 2015; in press.

[7] Balkan B and Ertan F. Production and properties of $\alpha$-amylase from Penicillium chrysogenum and its application in starch hydrolysis. Prep. Biochem. Biotechnol., 2005; 35: 169-178.

[8] Banea, J. P., Bradbury, J. H., Mandombi, C., Nahimana, D., Denton, I. C., and Katumbay, D. T. Effectiveness of wetting method for control of konzo and reduction of cyanide poisoning by removal of cyanogens from cassava flour. Food Nutri. Bulletin, 2014; 35(1): 28-32.

[9] Chi H.L.Z., X. Duan, L. Ma and L. Gao. Purification and characterization of extracellular amylase from the marine yeast Aureobasidium pullulans N13d and its raw potato starch digestion. Enzyme Microb. Technol., 2007; 40: 1006-1012.

[10] Chung YC, Kobayashi T, Kanai H, Akiba T, Kudo T. Purification and properties of extracellular amylase from the hyperthermophilic archaeon Thermococcus profundus DT5432. Appl. Environ. Microbiol., 1995; 61: 1502-1506.

[11] Cordeiro CAM, Martins MLL, and Luciano AB. Production and properties of $\alpha$-amylase from thermophilic Bacillus sp. Braz. J. Microbiol., 2002; 33: 57-61.

[12] Dar, G.H., Kamili, A.N., Nazir, R., Bandh, S.A., and Malik, T.A. Biotechnological production of $\alpha$-amylases for industrial purposes: Do fungi have potential to produce $\alpha$-amylases? Int. J. Biotechnol. Mol. Biol. Res., 2014; 5(4):35-40.

[13] de Souza, P.M. and Magalhães, P.O. Application of microbial $\alpha$-amylase in industry - a review. Braz. J. Microbiol., 2010; 41: 850-861.

[14] Doyle EM, Kelly CT, and Fogarty WM. The amylolytic enzymes of Penicillium amagasakiense. Biochem. Soc. Trans., 1988; 16: 181-182.

[15] Doyle EM, Kelly CT, Fogarty WM. The high maltoseproducing $\alpha$-amylase of Penicillium expansum. Appl. Microbiol. Biotechnol., 1989; 30:492-496.

[16] Elias, M., Wieczorek, G., Rosenne, S., and Tawfik, D. S. The universality of enzymatic rate- temperature dependency. Trends Biochem. Sci., 2014; 39(1): 1-7.

[17] Ertan F, Yagar H, and Balkan B. Some properties of free and immobilized $\alpha$-amylase from Penicillium griseofulvum by solid state fermentation. Prep. Biochem. Biotechnol., 2006; 36: $81-91$.

[18] Filtz, T. M., Vogel, W. K., and Leid, M. Regulation of transcription factor activity by interconnected posttranslational modifications. Trends Pharmacol. Sci., 2014; 35(2): 76-85.

[19] Fogarty WM, and Kelly CT. Recent advances in microbial amylases. In: Fogarty WM, Kelly CT, (eds). Microbial enzymes and biotechnology, London and New York. 1990; Pp. 71-133.

[20] F. Nartey and B. L. Møller. Amino acid profiles of cassava seeds (Manihot esculenta). Econ. Bot., 1976; 30(4): 419-423.

[21] Gauthier, G. M., and Keller, N. P. Crossover fungal pathogens: the biology and pathogenesis of fungi capable of crossing kingdoms to infect plants and humans. Fungal Gen. Biol., 2013; 61:146-157.

[22] Gupta A., Gupta D.R Modi and Yadava L.P. Production and characterization of a-amylase from Aspergillus niger. Biotechnol., 2008; 1:1-6.

[23] Gupta, R., Gigras, P., Mohapatra, H., Goswami, V.K.,Chauhan, B. Microbial $\alpha$-amylases: a biotechnological perspective. Process Biochem., 2003; 38:1599 - 1616.

[24] Hu, X., Wang, C., Wang, L., Zhang, R., and Chen, H. Influence of temperature, $\mathrm{pH}$ and metal ions on guaiacol oxidation of purified laccase from Leptographium qinlingensis. World J. Microbiol. Biotechnol., 2014; 30(4):1285-1290.

[25] Jadhav, S. B., Bankar, S. B., Granström, T., Ojamo, H., Singhal, R. S., and Survase, S. A. Enhanced stability of alcohol dehydrogenase by non-covalent interaction with polysaccharides. Appl. Microbiol. Biotechnol., 2014; 98(14): 6307-6316.

[26] Kathiresan K and Manivannan S. $\alpha$-Amylase production by Pencillium fellutanum isolated from mangrove rhizosphere soil. Afri. J. Biotechnol., 2006; 5(10): 829-932.

[27] Khedher IBA, Bressollier P, Urdaci MC, Limam F, Marzouki $\mathrm{MN}$. Production and biochemical characterization of Sclerotinia sclera otiorum $\alpha$-amylase ScAmy1: assay in starch liquefaction treatments. J. Food Biochem., 2008; 32: 597-614.

[28] Kumar, D., Yadav, K. K., Muthukumar, M., and Garg, N. Production and characterization of $\alpha$-amylase from mango kernel by Fusarium solani NAIMCC-F-02956 using submerged fermentation. J. Environ. Biol., 2013; 34(6): 10531058.

[29] Metin, K., Koc, O., Ateşlier, B. B., and Biyik, H.H. Purification and characterization of $\alpha$-amylase produced by Penicillium citrinum HBF62. Afr. J. Biotechnol., 2010; 9(45):7692-7701.

[30] Miller, G.L. Use of dinitrosalicylic acid Their purification, properties, action on starch and reagent for determination of reducing sugar. Anal. Chem., 1959; 31: 426-429.

[31] Nouadri T, Meraihi Z, Shahrazed DD, and Leila B. Purification and characterization of the $\alpha$-amylase isolated from Penicillium camemberti PL21. Afr. J. Biochem. Res., 2010; 4(6): 155-162.

[32] Oboh G. Isolation and characterization of amylase from fermented cassava (Manihot esculenta crantz) waste water. Afri. J. Biotechnol., 2005; 4 (10): 1117 - 1123.

[33] Ogugbue, C.J., Mbakwem-Aniebo, C. and Akubuenyi, F. Assessment of microbial air contamination of post processed garri on sale in markets. Afri. J. Food Sci., 2011; 5(8): $503-$ 512 .

[34] Okolo BN, Ire FS, Ezeogu LI, Anyanwu CU, Odibo FJC. Purification and some properties of a novel raw starchdigesting amylase from Aspergillus carbonarius. J. Sci. Food Agric., 2000; 81: 329-336.

[35] Osakwe, S.A. Effect of Cassava Processing Mill Effluent on Physical and Chemical Properties of Soils in Abraka and Environs, Delta State, Nigeria. Chem. Materials Res., 2012; 2 (7): 27-39. 
[36] Oyewole OB and Sanni LO. Constraints in traditional cassava processing: A case of 'fufu' production. In: Transformation Alimentaire Du Manioc (Cassava Food Processing). Editors: Tom Agbor Egbe, AlainBrauman, Dany Griffon, Serge Treche. Institut Francais de Recherche Scientifique Pour le Development en Cooperation (ORSTOM), Paris, France. ISBN 2-7099-1279-1. 1995; Pp. 523-529.

[37] Pandey, A., Nigam, P., Soccol, C.R., Soccol, V.Y.,Singh, D. and Mohan, R. Advances in microbial amylases. Biotechnol. Appl. Biochem., 2000; 31:135-152.

[38] Roy, A., Khanra, K., Mishra, A., and Bhattacharyya, N. Partial purification and characterization of amylase from a newly isolated Bacillus megaterium Strain KAN1 from fermented rice Handia. Am. J. Curr. Microbiol., 2014; 2(1): 1-5.

[39] Selvakumar P, Ashakumary L, Helen A, and Pandey A. Purification and characterization of glucoamylase produced by Aspergillus niger in solid state fermentation. Lett. Appl. Microbiol., 1996; 23: 403-406.

[40] Sindhu R. Isolation, purification and characterization of $\alpha$ amylase from Penicillium janthhinellum. Ph.D. Thesis. School of Biosciences, Mahatma Gandhi University. 2005; P. 175.

[41] Sinha, R., and Khare, S. K. Characterization of detergent compatible protease of a halophilic $<\mathrm{i}>$ Bacillus $</ \mathrm{i}>\mathrm{sp}$. EMB9: Differential role of metal ions in stability and activity. Biores. Technol., 2013; 145:357-361.
[42] Sun H, Zhao P, Ge X, Xia Y, Hao Z, Liu J, and Peng M. Recent advances in microbial raw starch degrading enzymes. Appl. Biochem. Biotechnol., 2010; 160: 988-1003.

[43] Tatsinkou, FB, Tavea F, Jiwoua C, Ndjouenkeu R. Screening of thermostable amylase producing bacteria and yeasts strains from some cameroonian soils. Afr. J. Microbiol. Res., 2009; 3(9): 504-514.

[44] Tatsinkou, FB, Tavea F, Jiwoua C, Ndjouenkeu R. Simultaneous production of raw starch degrading highly thermostable a-amylase and lactic acid by Lactobacillus fermentum 04BBA19. Afr. J. Biotechol., 2011; 10(34): 65646574.

[45] Uyoh EA, Udensio, Natwi V, and Urea I. Effect of different processing methods on cyanide content of garri from cultivars of cassava. J. Food Agric. Environ., 2007; 3(4): 105-107

[46] Vishnu, T. S., Soniyamby, A. R., Praveesh, B. V., and Hema, T. A. Production and optimization of extracellular amylase from soil receiving kitchen waste isolate Bacillus sp. VS 04. World Appl. Sci. J., 2014; 29(7): 961-967.

[47] Gornall A, Bardsmill CT, David MM. Determination of serum protein by means of biuret reaction. J. Biol. Chem., 1949; 177: 751-766. 